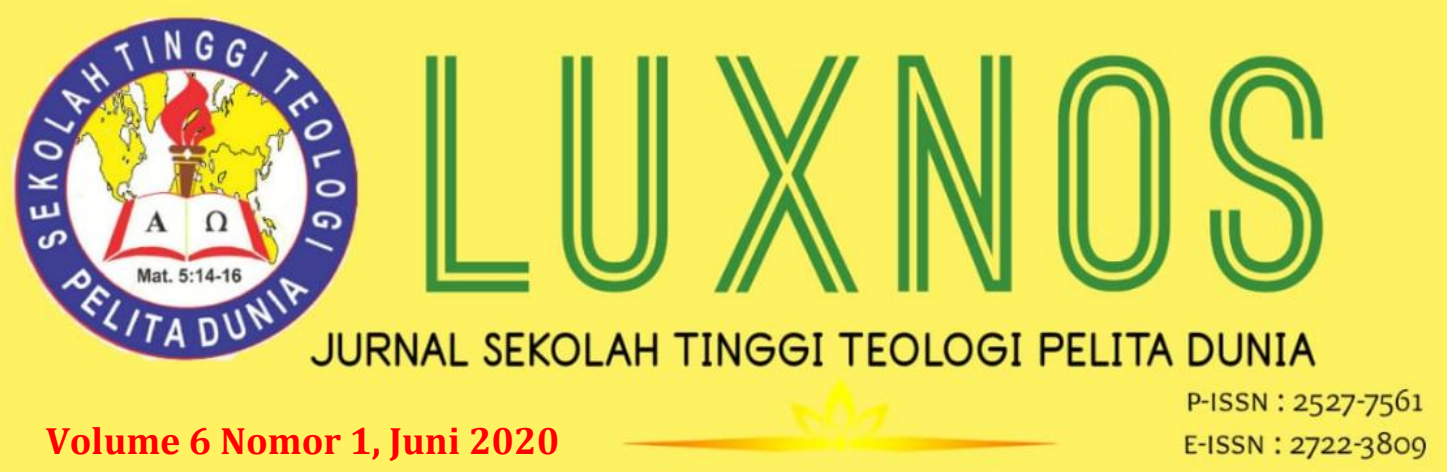

\title{
Kajian Teologis Terhadap Musik Gerejawi
}

\author{
Dapot Nainggolan, Sekolah Tinggi Teologi Pelita Dunia Tangerang \\ dapotnainggolan81@gmail.com
}

\begin{abstract}
Church music has its true meaning if it is understood based on the principles contained in the word of God. By having a correct understanding of the meaning, purpose, who, and how and when ecclesiastical music is performed, our worship of God through music and singing will build faith and glorify God. Church music and singing are absolutely based on God's will. Church music is not an option, but an obligation for every church in response to God's redemptive work in his life. Church music and singing are not in the framework of introducing one element to another in an arrangement of liturgical events, and not in the context of an enjoyable joint activity to sing favorite songs. Meeting with God through His maintenance work at all times, that is the motor that moves the music and hymns to God.
\end{abstract}

Keywords: Theology, Church Music.

Abstrak: Musik gerejawi menjadi benar maknanya bila dipahami berdasarkan prinsip-prinsip yang terkandung dalam firman Allah. Dengan memiliki pemahaman yang benar akan makna, tujuan, siapa, dan bagaimana serta kapan musik gerejawi itu dilakukan, maka penyembahan kita kepada Allah melalui musik dan nyanyian akan membangun iman dan memuliakan Allah. Musik dan nyanyian gerejawi mutlak didasari oleh kehendak Allah. Musik gerejawi bukan merupakan pilihan, melainkan kewajiban bagi setiap gereja sebagai respon atas karya penebusan Allah dalam hidupnya. Musik dan nyanyian gerejawi bukan dalam rangka sebagai pengantar antar unsur yang satu dengan unsur lainnya dalam sebuah susunan acara liturgi, dan bukan pula dalam rangka suatu aktifitas kegiatan bersama yang menyenangkan untuk menyanyikan lagu-lagu kesayangan. Perjumpaan dengan Allah melalui karya pemeliharaan-Nya pada setiap waktu, itulah yang menjadi motor yang menggerakkan musik dan nyanyian pujian kepada Allah.

Kata Kunci: Teologi, Musik Gerejawi. 


\section{Pendahuluan}

Beraneka ragam sebabnya mengapa musik gerejawi tidak menjadi prioritas dalam kehidupan setiap orang percaya. Mulai dari perasaan takut, malu hingga masalah-masalah musikalitas yang tidak begitu mumpuni telah menjadi alasan-alasan yang klasik dari sebagian orang-orang percaya. Di lain pihak ada juga yang beranggapaan bahwa bermain musik dan bernyanyi untuk Tuhan hanya dikhususkan pada waktu-waktu tertentu saja, seperti hari Minggu dan pada waktu-waktu perayaan hari-hari besar Gerejawi lainnya.

Sebaliknya ada orang-orang kristen sungguh tidak ada rasa takut ataupun malu untuk bernyanyi, melainkan bersemangat, namun demikian musik dan nyanyian pujian tersebut tidak lagi berada pada makna dan fungsinya yang tepat. Musik dan nyanyian gerejawi menjadi hanya semacam aktifitas keagamaan yang bergembira karena dapat menyanyikan lagu-lagu kesayangan mereka, serta musik dan nyanyian dipahami hanya sebatas media pengantar dalam urutan-urutan liturgi saja.

Pokok masalah dari kedua kelompok di atas sesungguhnya berada pada pemahaman yang tidak lengkap terhadap makna dari sebuah musik dan nyanyian gerejawi dalam tatanan iman Kristen. Pemahaman secara teologis yang keliru terhadap musik dan nyanyian-nyanyian gerejawi bukan saja menjadikan orang malu menyembah Allah, namun juga menjadikan musik gerejwi tersebut pada tempat yang tidak tepat dalam struktur bangunan iman Kristen.

Ketika penulis membaca sebuah buku yang berjudul Pujian Dan Penyembahan yang ditulis oleh Graham Kendrikck, mengemukakan beberapa pokok diskusi dan pertanyaan yang dapat merepresentasikan pemahaman-pemahaman yang keliru dari sebagaian orang - orang Kristen dalam memahamai makna musik dan puji-pujian sebagai bagian dari unsur-unsur liturgi gereja. Beberapa pokok-pokok diskusi dan pertanyaan tersebut, antara lain:

- Ada orang yang tidak mau menghadiri sebuah kebaktian kecuali ibadahnya memakai buku nyanyian terbitan abad-abad ke enambelas atau zaman reformasi yang diaggap bersifat tenang dan meneduhkan hati. Sebaliknya ada orang - orang yang tidak mau datang ke kebaktian kecuali ia bebas untuk bernyanyi sambil mengangkat tangan dan menari.

- Peribadahan diperdebatkan berkenaan dengan apakah harus memakai oragan dan paduan suara atau memakai drum atau gitar?

- Apakah ketika bermusik dan bernyanyi dalam sebauh kebaktian harus dilakukan dengan suara yang keras dan bergembira atau suara yang lembut?

- Apakah penyembahan merupakan kegiatan bersama yang menyenangkan untuk menyanyikan lagu-lagu kesayangan? 
- Apakah penyembahan merupakan suatu aktifitas orang Kristen untuk menyalurkan perasaan emosi mereka. Apakah itu merupakan suatu pengantar dari penyampaian khotbah di gereja? ${ }^{1}$

Dengan demikian bahwa musik gerejawi tersebut bukan lagi berpusat pada Allah melainkan telah didasari oleh polemik-polemik kesenangan-kesenangan manusia. Perdebatannya bukan lagi bagaimana menyenangkan hati Tuhan melainkan bagaimana menyanyikan lagu-lagu kesayangan yang menghangatkan emosi jiwa demi mencapai euforia tradisi beragama.

Pokok-pokok diskusi serta perdebatan-perdebatan semacam di atas telah menimbulakan suatu kegelisahan yang dalam bagi penulis sehingga terdorong untuk mengkaji lebih dalam makna teologis apa sesungguhnya yang terkandung dalam musik gerejawai tersebut? Sebagai unsur yang sangat penting dalam sebuah penatalayanan gereja maka musik gerejawi sesungguhnya bertujuan bukanlah untuk menyenangkan manusia melainkan mutlak untuk memuliakan Tuhan. Musik merupakan kehendak Allah (Maz. 150:6). Allah yang Maha Mulia berkehendak untuk disembah oleh umat-Nya melalui musik dan nyanyian yang indah (band. Nehemia 12:27-43). Gereja Tuhan dengan sungguh-sungguh mempersiapakan dirinya untuk menaikkan setiap mazmur bagi nama-Nya yang Agung. Keperkasaan tangan-Nya menjadi alasan menyembah-Nya dengan musik, nyanyian dan tarian yang indah. Begitulah musik gerejawi menjadi sangat penting dalam kehidupan orang-orang percaya.

Will Metzger dalam bukunya yang berjudul Tell The Truth mengatakan bahwa, sesungguhnya penyembahan merupakan agenda Allah yang nomor satu dalam kehidupan manusia, sementara penginjilan adalah sebagai agenda Allah yang nomor dua. ${ }^{2}$ Artinya bahwa pada waktu tertentu penginjilan memang akan berhenti, namun penyembahan kepada Allah akan kekal selamanya. Penyembahan merupakan tujuan akhir dari pada penginjilan. Dan seterusnya bahwa penyembahan di dalam gereja juga merupakan motor penggerak bagi pelayanan pemberitaan Injil. Gereja- gereja yang menyembah Allah secara benar akan terdorong untuk melakukan penginjilan. Sebuah penggalan kalimat John Piper yang dicatat dalam bukunya Will Metzger tadi mengatkan bawaha; "Misi bukanlah sasaran utama dari gereja, melainkan penyembahan. Misi ada karena penyembahan tidak ada. Penyembahanlah yang tertinggi, bukan misi, karena Allah yang tertinggi, bukan manusia". ${ }^{3}$ Musik gerejawi

\footnotetext{
${ }^{1}$ Graham Kendrick, Pujian Dan Penyembahan, Mimeery Press: Jakarta, 1984, hlm. 13.

${ }^{2}$ Will Metzger, Tell The Truth, Momentum: Surabaya, 2005, hlm.181.

${ }^{3}$ Ibid.
} 
adalah alat utama yang digunakan oleh manusia dalam menyembah Allah (band. Mazmur 150:3-5).

Oleh karena betapa pentingnya unsur musik gerejawi tersebut dalam rangka penyembahan gereja kepada Allah, maka aspek-aspek yang terkandung dalam musik gerejawi tersebut menjadi sebuah keharusan untuk dikaji secara teologis supaya pelayanan musik dan nyanyian gereja kepada Allah menjadi benar. Beberapa aspek dalam musik dan nyanyian gerejawi yang perlu dikaji secara teologis supaya menjadi tepat dan selaras dengan kehendak Allah, antara lain;

1. Dasar Musik Gerejawi;

2. Tujuan Musik Gerejawi;

3. Bentuk Musik dan Nyanyian Selaras Dengan Alkitab;

4. Siapa Dan bagaimana Mempersembahan Musik Gerejawi Kepada Tuhan?

5. Kapan Dan Dimana Musik Gerejawi Dipersembahakan Kepada Tuhan?

Dengan demikian kelima aspek dari musik gerejawi tersebut akan diuraikan satu persatu dalam penelitian ini, sehingga setiap pembaca kembali diingatkan dan disegarkan pemahamannya mengenai musik dan nyanyian pujiannya kepada Tuhan dan pada akhirnya dapat membangun kualitas iman setiap gereja demi hormat dan kemuliaan bagi Allah.

\section{Metode Penelitian}

Pada penelitian ini, akan menggunakan pendekatan kualitatif. Dengan lebih menitikberatkan pada kajian pustaka atau literatur. Untuk memperoleh sebuah hasil yang kualitatif tentang pandangan teologis terhadap musik gerejawi.

\section{Hasil dan Pembahasan}

Sebelum lebih jauh penulis menguraiakan secara teologis satu demi satu aspek dari musik gerejawi tersebut, maka terlebih dahulu penulis memberikan penjelasan musik secara umum dan musik gerejawi secara khusus. Tujuannya adalah supaya memperjelas batas cakupan dari apa yang disebut dengan istilah musik gerejawi.

\section{Defenisi Musik Secara Umum}

Winnardo Saragih dalam bukunya yang berjudul; Misi Musik, memberikan sebuah defenisi yang sederhana namun cukup untuk menjelaskan apa yang dimaksud dengan musik, yaitu; perpaduan nada dan suara dari berbagai alat yang menghasilkan keharmonisan dengan tujuan untuk mengekspresikan emosi dan ide". ${ }^{4}$ Dari pengetian

${ }^{4}$ Winnardo Saragih, Misi Musik, Menyembah atau Menghujat Allah?, Yogyakarta: Penerbit Andi: 2008, hlm. 2. 
ini dapat dikembangkan lagi bahwa musik itu menyangkut dua hal yakni yang pertama musik merupakan sebuah karya seni berkenaan dengan harmonisasi nadanada yang merupakan ekspresi dari sebuah ide ataupun emosi jiwa. Dan yang kedua adalah musik adalah sebagai ilmu pengetahuan, yaitu kemampuan seseorang dalam menggubah, memadukan ataupun menggabungkan nada-nada dan syair dalam sebuah nyanyian.

Musik menjadi umum dan hampir tidak bisa dipisahkan dari peradaban kehidupan manusia di bumi ini. Di mana-mana ada musik! Orang pergi ke tempattempat keramaian seperti mall, supermarket, disana selalu diperdengarkan musikmusik dengan jenis-jenis tertentu dengan tujuan menghibur para pengunjung yang datang. Di bus, di kantor, di sekolah, musik menjadi biasa kita jumpai dan nikmati, bahkan di perladangan sekalipun pun ketika orang sedang bekerja tak jarang mereka menikmati alunan musik dari alat pemutar musik mereka untuk sekedar menghibur dan memberi semangat tatkala sedang mengerjakan pekerjaan ladang mereka. Sehingga hampir bisa disimpulkan bahwa setiap manusia pasti senang dengan musik paling tidak senang untuk mendengarkannya, terlepas dari perbedaanperbedaanjenis musik yang disukai oleh masing-masing orang atau kelompok masyarakat. Perbedaan kesukaan terhadap jenis-jenis musik sangat dipengaruhi oleh latarbelakang nilai-nila kebudayaan masing-masing orang. Sebagaimana setiap bangsa memiliki perbedaan dalam mengekspresikan cintanya kepada orang, demikian halnya dengan musik dan nyanyian. Setiap orang dari berbagai latarbelakang budaya akan berbeda-beda dalam mengekspresikan karya musik dan nyanyiannya.

Musik memiliki peran penting dalam kehidupan manusia. Sejak dikandungan manusia sudah mulai diperdengarkan musik-musik tertentu. Hal itu diyakini mampu merangsang kecerdasan otak bayi dalam kandungan. Selain itu, musik juga telah dipergunakan sebagai alat terapi bagi orang-orang yang memiliki sakit-penyakit tertentu. Oleh karena itu musik menjadi begitu sentral dalam kehidupan manusia, sehingga musik dapat dikatakan sebagai bagian dari perilaku sosial yang kompleks dan universal. Setiap masyarakat memiliki hal yang disebut dengan musik. Semua warga masyarakat adalah potret dari kehidupan musikal. ${ }^{5}$ Ada kalanya memang setiap orang tidak mampu menciptakan dan memainkan sebuah alat musik, namun untuk menikmatinya seringkali tidak memerlukan keahlian khusus. Mudah mengetahui apakah seseorang telah mamapu menikmait sebuah alunan musik. Bahasa tubuh seseorang bisa menjadi sebuah indikator bahwa dia sedang menikmati irama dan dinamika-dinamika musik yang sedang ia dengar. Menurut penelitian

\footnotetext{
${ }^{5}$ Djohan, Psikologi Musik, DIY: Kanisius, 2001, hlm.. 31.
} 
bahwa tubuh manusia cenderung merespon kecepatan irama, nada, dan suara dari luar. Ketika seseorang mendengar suara atau musik yang kecepatan ritmenya diantara 60 sampai dengan 90 kali per menit, maka manusia akan dibuat lebih rileks karena kecepatan yang demikian itu hampir selaras dengan detak jantung yang sempurna dari manusia. ${ }^{6}$ Begitulah musik mewarnai kehidupan manusia.

Plato (sekitar tahun 427-347 SM) dan Aristoteles menguraikan teori tentang ethos, atau sifat moral dan efek-efek yang dihasilkan oleh musik. Menurut Aristoteles, musik menirukan dan menggambarkan emosi serta keadaan jiwa manusia. Jadi kalau seseorang mendengarkan musik, emosinya sendiri akan dipengaruhi menjadi serupa dengan sifat musik tersebut. ${ }^{7}$ Dengan demikian ada jenis-jenis musik yang dapat membangkitkan emosi dan sifat yang kurang baik. Dengan kata lain, jika seseorang mendengar jenis musik yang kurang baik, ia akan menjadi manusia yang kurang baik. Sebaliknya, jika ia mendengar jenis musik yang baik, ia kan menjadi orang yang baik. Plato dan Aristoteles berpendapat bahwa beberapa jenis musik tertentu harus dikontrol demi kebaikan masyarakat. Menurut mereka, kesenian dan pendidikan tanpa peraturan akan menghasilkan orang yang tidak bermoral dan masyarakat yang bersifat anarkis. ${ }^{8}$

Oleh karena itu, beberapa ahli musik gerejawi telah dipengaruhi teori dari Plato tersebut dan akhirnya menentang musik yang dipakai dalam ibadah-ibadah yang menganut aliran Dionysian (Romantik/Gembira), yang dianggap hanya membangkitakan satu sifat semangat lahiriah (kedagingan), kegemparan dan sifatsifat lain yang dianggap kurang baik. Mereka lebih suka aliran musik Apollonian (Klasik) yang cenderung pada rasa ketenangan dan dorongan spiritual terhadap orang yang memainkannya dan yang mendengarkan musik tersebut. ${ }^{9}$

Sebuah musik dan nyanyian bisa menjadi baik ketika dengan tepat waktu dan fungsinya dipergunakan. Ada banyak jenis-jenis musik yang nada-nadanya dan lirikya sangat membangkitkan semangat namun tetap mendorong untuk lebih giat melakukan kebaikan-kebaikan. Namun ada pula musik yang menjadi tidak baik, ketika nada-nadanya dan liriknya lebih menggairahkan orang untuk melakukan tindakan-tindakan yang kurang baik. Oleh karena ada baiknya untuk terus bijaksana dalam mencipta, memainkan dan mendengarkan sebuah musik dan nyanyian.

${ }^{6}$ Winnardo Saragih, hlm. 3

${ }^{7}$ Rhoderick J. McNeill, Sejarah Musik 1, Jakarta: BPK Gunung Mulia, 2016, hlm. 5

8 lbid.

9 Ibid. 


\section{Defenisi Musik Gerejawi}

Istilah gerejawi adalah menyangkut hal-hal yang berkenaan dengan gereja. Sehingga apabila musik dikaitkan dengan istilah gerejawi maka secara literal itu artinya bahwa musik yang dimaksud adalah segala jenis musik yang berkenaan dengan gereja. Musik yang berkenaan dengan gereja artinya adalah segala jenis musik dan nyanyian pujian yang dipakai oleh gereja untuk menyembah Allah. Pengertian gereja yang dimaksud dalam konteks musik gerejawi ini tidaklah terbatas pada gereja sebagai organisasi, melainkan pada makna gereja yang paling hakiki, yaitu persekutuan orang-orang percaya, orang-orang yang telah dipanggil Tuhan menjadi umat-Nya.

Musik Gerejawi merupakan sebuah respons dari orang-orang percaya terhadap keagungan dan keperkasaan tangan Allah yang telah berkarya dalam kehidupannya (band. Maz. 150). Musik gereja bukan saja berlangsung dalam kontekskonteks liturgi peribadahan gereja saja, namun juga harus nyata pada setiap kehidupan keseharian orang percaya. Allah bertahta diatas pujian, sehingga Ia menghendaki setiap ciptaan-Nya datang untuk memuji dan menyembah-Nya. Itulah sebabnya jauh sebelum manusia diciptakan, Allah telah mneciptakan malaikat dan menentukan diantara malaikat-malaikat itu yang dikhususkan untuk menaikkan pujian dan penyembahan kepada-Nya (lihat Yehezkiel 28:11-19). ${ }^{10}$

Musik Gereja adalah salah satu unsur yang paling penting dalam teologi. Selain daripada khotbah, musik adalah unsur utama dalam penatalayanan peribadahan umat percaya. Itulah sebabnya musik menjadi perhatian dari banyak kalangan didalam gereja. Mulai dari alat-alat musiknya, nada-nada harmonisasinya, serta liriklirik pujiannya harus seirama dengan maksud-maskud musik itu sendiri menurut Firman Allah. Sebagaimana musik berasal dari Allah, kita wajib mengembalikannya kepada Allah dan memuliakan-Nya. ${ }^{11}$

\section{Kajian Teologis}

Orang-orang yang sepenuhnya percaya kepada Allah dan yang telah melihat nyata keperkasaan tangan-Nya dalam kisah hidup mereka akan dengan penuh sukacita dan tanpa memiliki kekuwatiran tatkala mereka menyembah Allah sekalipun mungkin ancaman nampak jelas dihadapannya. Demikianlah kesaksian Alkitab mengenai anak-anak Tuhan yang menyembah Allah dengan musik dan nyanyian pujian mereka. Ketika bangsa Israel keluar dari tanah perbudakan bangsa Mesir, mereka mampu menyeberangi Laut Teberau berkat pertolongan dari Allah, sehingga kemudian Musa bersama seluruh bangsa Israel itu bernyanyi dan memuji Allah.

${ }^{10}$ Lamar Boschman, Musik Bangkit Kembali, Jakarta: Yayasan Pekabaran Injil Imanuel, 2001, hlm.2

${ }^{11}$ Winnardo Saragih, hlm. 74. 
Sementara Miryam saudari Musa beserta seluruh perempuan Israel bersukacita dan menari-nari sambil membunyikan alat musik rebana sebagai ungkapan rasa syukur mereka atas pertolongan yang diberikan oleh Allah bagi mereka (lihat Keluaran 14 dan 15). Keperkasaan tangan Allah yang telah menyelamatkan bangsa Israel telah mendorong mereka untuk memuji dan menyembah Allah.

Demikian pula Daud, si penggembala muda itu dalam 1 Samuel 17 dikisahkan bahwa dengan yakin dan penuh kepercayaan kepada Allah datang menghampiri barisan para tentara-tentara Allah Israel yang sedang ketakutan. Daud melihat betapa kegelisahan dan ketakutan nampak jelas diwajah mereka ketika sedang berhadapana dengan seorang tentara bangsa Filistin yang bernama Goliat. Cemoohan demi comoohan dari Goliat semakin menambah rasa frustasi dari semua bala tentara yang dimiliki oleh raja Saul ketika itu. Namun Daud si penggembala itu tidak tahan akan celotehan orang Filistin tersebut. Dia menawarkan diri untuk menghadapi Goliat tentara Filistin tersebut. Keyakinan dan keberanian yang dimiliki oleh Daud menjadi semacam pembeda dari tentara-tentara yang diliputi rasa frustasi dan keputusasaan itu. Sudah tentu bahwa anggapan dari para serdadu terhadap seorang anak muda yang tidak terlalu meyakinkan karena postur tubuh yang tidak begitu besar, namun Daud begitu yakin bahwa ia sanggup mengalahakan Goliat.

Saudara-saudara Daud pun tidak begitu yakin dengannya bahkan mereka sangat marah dengan sikap yang ditunjukkannya itu. Apa gerangan yang meyakinkan Daud? Yang meyakinkan Daud adalah perjumpaannya dengan Alah dalam realitarealita kehidupannya. Allah yang "tidak sanggup" menurut iman para tentara Israel namun bagi iman Daud adalah Allah yang "sanggup". ${ }^{12}$ Dalam 1 Samuel 17:37 berbunyi; Pula kata Daud:"Tuhan yang telah melepasakan aku dari cakar singa dan dari cakar beruang, Dia juga akan melepasakan aku dari tangan orang Filistin itu". Relevansi kisah keberanian Daud ini pada konteks penyembahan kepada Allah adalah bahwa kemampuan dan keberanian seseorang untuk menaikkan pujian-pujian dan penyembahan kepada Allah tidak akan pernah dipengaruhi oleh tanggapantanggapan sinis dari orang-orang lain. Musik dan nyanyian bagi pengagungan Allah tidak dipengruhi oleh ketakutan-ketakuan orang lain. Seperti Daud yang masuk kedalam situasi dimana ketakukatan telah melumpuhkan orang-orang lain, namun ia tidak. Karena secara personal ia telah mengalami kemahakuasaan Allah. Beranjak dari keyakinan pada realitas Allah, Daud berbicara dan bertindak. Daud telah berjumpa dengan Allah dan itu telah mengubahkan dia. ${ }^{13}$ Maka tidak heran dalam sejarah bangsa Israel raja Daud menjadi seorang yang sangat sungguh-sungguh mempersembahkan berbagai jenis musik, mazmur dan kidung pujian kepada Allah.

12 Will Metzger, Tell The Truth, hlm. 176.

13 Ibid. 
Dalam Kitab Kisah Para Rasul 16 memberikan satu gambaran bahwa nyanyian dan puji-pujian kepada Allah tidak dibatasi oleh ruang dan waktu serta penderitaan yang sedang melanda. Penjara seharusnya menjadi tempat yang mencekam dan penuh kengerian. Penjara menjadi tempat yang memisahkan dari orang-orang yang terkasih seperti keluarga dan para sahabat. Deraan demi deraan pun seringkali dialami oleh seseorang yang terpenjara. Namun bagi Paulus hal itu tidak menjadi penghalang yang serius untuk tetap memuji dan menyembah Allah. Ketika ia dimasukkan ke dalam penjara di Filipi dengan suara yang lantang pada waktu tengah malam ia dan Silas bernyanyi dan berdoa kepada Allah. Tindakan demikian itu sungguh tidak lazim bagi kebanyakan orang, namun bagi Paulus memuji dan menyembah Tuhan tidak dapat dihalangi oleh ruang, waktu dan situasi apapun. Nyanyian pujian dengan suara yang keras meggambarkan sebuah keyakinan iman mereka untuk menyembah kepada Allah, sehingga nyanyian itu terdengar oleh orangorang di bilik yang lain dalam penjara itu (band. ayat 25). Apa yang mendorong Paulus mampu melalukan penyembahan itu kepada Allah pada tempat dan situasi yang tidak begitu normal pada saat itu? Jawabannya ialah keyakinan Silas dan Pulus akan kuasa Allah. Perjumpaan mereka kepada Yesus Kristus yang telah menyelamatkan mereka dan yang telah menyatakan perlindungan-Nya bagi perjalanan hidup mereka dimasa lampau telah meneguhkan iman dan keberaniannya. Sehingga peristiwa- peristiwa yang mungkinakan terjadi (baik atau buruk) di hidup mereka kelak semuanya diletakkan pada otoritas Allah. Bukan prasangka-prasangka dan ancaman-ancaman dari manusia yang menjadi rujukan penyembahan Paulus kepada Allah. Tetapi karya penebusan Kristus yang nyata telah mendoroang penyembahannya kepada Allah. Dengan demikian kuasa akan nyata dalam setiap pujian dan penyembahan kepada Allah.

\section{Dasar Musik Gerejawi}

\section{a. Perjanjian Lama}

Musik merupakaan kesukaan Allah, dengan demikian telah mendorong setiap umat untuk mempersembahkannya kepada Dia. Tidak begitu lama dari waktu penciptaan alam semesta dan manusia, Alkitab telah berbicara tentang musik. Generasi ketujuh dari manusia pertama, yaitu Yubal dalam Kejadian 4:21 dikatakan, dialah yang menjadi bapa orang yang memainkan kecapi dan suling. Sebuah fakta yang jelas betapa Allah menghendaki musik dimainkan oleh umat-Nya untuk memuliakan-Nya. Begitu banyak ayat firman Allah yang menyatakan bahwa Allah menghendaki umat-Nya bernyanyi bagi-Nya. Mazmur 100:2b berkata; "....datangnlah ke hadapan-Nya dengan sorak-sorai (bernyanyi)". Mazmur 95:2, berbunyi; "Biarlah kita menghadap wajah-Nya dengan nyanyian syukur, bersorak-sorai bagi-Nya dengan 
nyanyian mazmur". Penyembahan orang-orang percaya kepada Allah bukanlah pilihan tambahan. Memuji Allah merupakan kehendak dan perintah Allah bagi umatNya. Baik Perjanjian Lama maupun Perjanjian Baru, perintah-perintah untuk memuji, memuliakan, menaikkan pujian, bersorak, mengucap syukur, menyembah, berlutut, memebawa korban, meninggikan, dan lain sebagainya menjadai tema-tema utama. ${ }^{14}$ Inilah dasar yang pertama bagi musik gereja; bahwa Allah bertahta diatas puji-pujian. Ia menghendaki umat-Nya menyembah dan memuji-Nya.

Mengapa Allah layak dipuji? Karena Dia adalah Allah yang kekal, Agung dan Mulia. Kemuliaan, Kemahakuasaan, dan keperkasaan tangan-Nya adalah dasar dan motivasi dari setiap musik dan nyanyian gerejawi. Mazmur 150:2 berbunyi; Pujilah Dia karena Segala keperkasaan-Nya, Pujilah Dia sesuai dengan kebesaran-Nya yang hebat.Musik gereja adalah respons manusia atas karya Allah melalui alam semesta ini dan secara khusus respons atas karya penebusan-Nya. Inilah dasar dan motivasi yang kedua bagi musik gereja menurut Perjanjian Lama (band. Mazmur 66:2, 3).

\section{b. Perjanjian Baru}

Ketika perempuan Samaria yang dikisahkan dalam Kitab Injil Yohanes 4 pada tengah hari pergi untuk menimba air dari sumur Yakub menunjukkan sebuah ketidak laziman dari orang-orang pada umumnya yang bilamana mau mengambil air adalah pada pagi atau petang hari. Namun hal itu sudah biasa ia lakukan sebab ia adalah orang yang terkucil secara sosial. Semua orang pasti mencemooh dia sebab riwayat hidupnya banyak mencatat peristiwa-peristiwa yang tidak baik secara moral. Ia banyak hubungan asamara dengan para kaum lelaki, paling tidak Alkitab mencatat ada enam laki-laki. Masyarakat menghindari dia, dan ia pun menghindari masyarakat. Sehingga kesendirian dalam melakukan aktifitas sudah terbiasa bagi perempuan Samaria. Pertanyaannya adalah, apakah ia tidak peduli pada pendapat orang lain? Jawabannya adalah peduli. Tak ada seorang pun dari manusia yang tidak peduli dengan pendapat orang. Secara tidak langsung bahwa pendapat orang telah ikut berpartisipasi membentuk perilaku kita. Namun apa yang mengubahakan perempuan samaria mampu menjadi saksi yang tidak malu bercerita kepada orang lain tentang Yesus Kristus? Jawabannya ialah perjumpaannya dengan Yesus Kristus secara pribadi yang telah mengubahkan dan meyakinkan dia untuk menjadi saksi-Nya. ${ }^{15}$ Air hidup kekal yang diberikan oleh Yesus itulah yang mendorong untuk menyembah dan melayani-Nya. Karya penebusan Allah didalam Yesus Kristus serta pemeliharaan Allah Roh Kudus adalah dasar dari setiap melodi dan nyanyian penyembahan kita kepada-Nya.

${ }^{14}$ Graham Kendrick, Pujian Dan Penyembahan, hlm. 59.

${ }^{15}$ Will Metzger, Tell The Truth, hlm. 177. 
Dalam Efesus 5:17-21 menasihatkan supaya setiap orang percaya mengerti kehendak Allah yaitu kepenuhan didalam Roh untuk menaikkan mazmur dan kidung pujian serta nyanyian rohani kepada Allah. Bagian ini hampir sama dengan yang ada dalam Kolose 3:16, jemaat juga diajak untuk menaikkan mazmur, kidung pujian dan nyanyian. Hanya dalam Kolose 3:16, nyanyian dan mazmur serta kidung pujian merupakan bukti pengajaran Yesus (The words of Christ) yang tinggal di dalam diri setiap orang percaya. Musik yang dibicarakan dalam Efesus 5:18-21 telah menjelaskan bahwa nyanyian dan pujian kepada Tuhan adalah merupakan bukti atau ciri khas yang utama dari kehidupan orang-orang percaya. Orang yang percaya kepada Kristus haruslah menjauhi kehidupan duniawi seperti mabuk-mabukan, akan tetapi sebaliknya mereka harus selalu dipenuhi dengan hikmat Roh Kudus. Seseorang yang dipenuhi oleh Roh akan selalu terdorong untuk menaikkan mazmur, kidung pujian dan nyanyian - nanyian rohani kepada Allah, sebab Allah menghendakinya.

\section{Tujuan Musik Gerejawi}

\section{a. Perjanjian Lama}

Sebagaimana musik gerejawi adalah di dasari oleh kehendak Allah dan perintah Allah, maka musik gerejawi tersebut mutlak bertujuan untuk memuliakan Allah. Musik gereja bukan sekedar pengantar untuk menyambut khotbah dalam sebuah kebaktian, bukan pula semata-mata aktifitas orang-orang Kristen untuk menyalurkan perasaan emosi mereka. Penyembahan juga bukan merupakan kegiatan bersama yang menyenangkan karena menyanyikan lagu-lagu kesayangan, melainkan bertujuan untuk menyatakan kebesaran Allah. Salah satu dari kebenaran yang ajaib mengenai Allah yang benar, yang telah dinyatakan kepada kita melalui Yesus Kristus adalah bahwa Ia sepenuhnya dan sama sekali layak untuk menerima penyembahan kita. ${ }^{16}$ Inilah alasan sekaligus tujuan utama dari sebuah musik gerejawi.

Dalam 2 Raja-raja 17:35-36 berbunyi; Tuhan telah mengadakan perjanjian dengan mereka dan memberi perintah kepada mereka: "Janganlah berbakti kepada Allah lain, jangnlah sujud menyembah kepadanya, janganlah beribadah kepadanya dan janganlah mempersembahkan korban kepadanya. Tetapi Tuhan yang menuntun kamu dari tanah Mesir dengan kekuatan yang besar dan dengan tangan yang teracung, kepada-Nyalah kamu harus berbakti, kepada-Nyalah kamu harus sujud menyembah dan mempersembahkan korban.Pujian tidak tergantung pada perasaan subjektifitas umat, melainkan didasarkan pada karya kebesaran Tuhan terhadap umat. Sehingga hanya kepada-Nya sajalah diberi kemuliaan. "Bukan kepada kami, ya TUHAN, bukan

\footnotetext{
${ }^{16}$ Graham Kendrick, Pujian Dan Penyembahan, hlm. 64.
} 
kepada kami, tetapi kepada nama-Mulah diberi kemuliaan, oleh karena kasih-Mu, oleh karena setia-Mu" (Maz. 115:1).

\section{b. Perjanjian Baru}

Banyak gereja telah meremehkan Allah karena tradisi-tradisi mereka dan karena pemahaman teologi mereka yang diringkas dan dibuat sesederhana mungkin tergantung kebutuhan umat. Mereka menyesuaikan Dia dengan segmen-segmen musikalitas kedagingan mereka, dan memandang-Nya sebagai Allah yang membuat mereka nyaman. ${ }^{17}$ Akibatnya kaidah-kaidah alkitabiah bukan menjadi ukuran final dalam bermusik dan bernyanyi, melainkan subjektifitas-subjektifitas pengalaman rohani dijadikan dogma dalam musik dan nyanyian. Manusia menjadi pusat dan tujuan dari sebuah musik gereja, bukan Allah. Di lain pihak musik gereja hanya dipahamai sebagai pengantar dan penghubung setiap unsur-unsur dalam sebuah peribadahan (liturgi). Musik dan nyanyian hanya sebatas media untuk mengiringi pengumpulan persembahan dalam kebaktian gereja. Inilah bentuk kekeliruan dari orang-orang percaya dalam memahami makna tujuan dari sebuah musik gerejawi.

Musik gerejawi selalu dan hanya bertujuan untuk memuliakan Allah (band. Ef. 5:19,20, Wahyu 7:12). Salah satu nyanyin dalam Kitab Wahyu pasal 5:9-10 yang dinyatakan di sana sebagai Anak Domab yang telah tersembelih layak menerima nyanyian; "Dan mereka menyanyikan suatu nyanyian baru katanya;Engkau layak menerima gulungan kitab itu dan membuka materai-materainya; karena Engkau telah disembelih dan dengan darah-Mu Engkau telah membeli mereka bagi Allah dari tiaptiap suku dan bahasa dan kaum dan bangsa."Musik gereja bukan bertujuan seolaholah ingin memaksa Tuhan datang menghampiri dan mengabulkan setiap permohonan mereka yang bernyanyi. Sehingga ada kalanya sebuah musik dan naynyian dengan cara berulang-ulang dinyanyikan dalam satu perayaan kebaktian dengan tujuan demikian itu. Bermain musik dan bernyanyi dengan sambil mengangkat tangan, menangis atau menari adalah ekspresi iman yang telah merespon kuasa Tuhan yang telah nyata dalam hidup. Sehingga dengan nyanyian itu, orang percaya ingin bersyukur kepada Allah. Ada kalanya memang sebuah nyanyian memiliki corak seperti sebuah permohonan, namun demikian bagaimanapun sifat dari sebuah musik gereja adalah tetap merupakan sebuah ungkapan pengakuan iman akan providensia Allah bagi umat baik sekarang maupun di masa yang akan datang (band. Filipi 4:6, Mazmur 23). Dengan keyakinan dan pengakuan itu setia gereja menaikkan nyanyian syukur untuk menyembah dan memuliakan-Nya.

17 Istilah "nyaman" disini bukan dalam konteks tidak kuwatir, melainkan memiliki arti bahwa nyanyian yang memberi kepuasan dan membangkitkan gairah kesenangan daging. 


\section{Bentuk Musik dan Nyanyian Selaras dengan Alkitab}

Segala jenis alat musik sesunggunya tidak menjadi masalah ketika digubah dengan baik. Digubah dengan baik artinya bahwa segala nada-nada yang dihasilkan melalui gubahan atau aransemen itu haruslah yang membangkitkan iman orangorang percaya untuk melayani dan memuliakan Allah. Sebaliknya bahwa segala nadanada yang hanya membangkitkan gairah kedagingan manusia sungguh tidak layak untuk dipersembahkan kepada Tuhan. Perubahan bentuk-bentuk musik memang sebuah keniscayaan, hal itu seiring dengan dinamika kebudayaan yang mempengaruhi jenis-jenis alat musik zaman demi zaman. Namun demikian bentuk musik bukan alasan utama yang dapat menghalangi penyembahan kita kepada Tuhan. Yang terpenting adalah bahwa segala bentuk musik harus bertujuan untuk mendemonstrasikan keagungan Allah. Demikian pula dengan teks atau lirik dari sebuah nyanyian gereja harus memenuhi prinsip -prinsip teologi Kristen. Teks dari sebuah nyanyian gerejawi harus alkitabiah yang mampu memberi pengajaran tentang sifat-sifat Allah yang dinyatakan dalam Alkitab. Pengajaran kepada yang menyanyikannya maupun kepada yang mendengar. Antara melodi dan teks harus selaras untuk membangun kasih kita kepada Allah. Perpaduan antara melodi atau nada-nada dengan teks nyanyian akan mengungkapkan keagungan Allah.

Sebuah bentuk musik harus mendukung syair nyanyian dalam menceritakan karya-karya Allah. Ada kalanya sebuah jenis musik bisa menjadi tidak selaras dengan maksud teks naynyain ketika jenis musiknya hanya berpatokan pada selera atau kesenangan pribadi. Sebagai contoh, bisa dibayangkan bilamana lagu yang berjudul "Suci, Suci, Suci" nyanyian dari Kidung Jemaat nomor 2 yang diciptakan oleh Reginald Heber $^{18}$ lalu diubah melodi musiknya menjadi semacam melodi yang memiliki cengkok seperti melodi dangdut yang riang-gembira; maka dapat dipastikan bahwa melodi cengkok dangdut itu tidak akan cocok atau selaras dengan makna yang terkandung di dalam teks nyanyian; Suci, Suci, Suci tersebut sebagaimana lagu itu ingin bercerita tentang ke-Maha-suci-an Allah Tritunggal. Memang hal demikian ini telah menjadi sebuah perdebatan di kalangan para ahli musik gerejawi berkenaan dengan apakah lagu yang jenis melodinya bergembira tidak mampu mengutarakan kemahakuasaan dan kemahasucian Allah? Namun demikian tentu bukan seperti itu memahaminya, melainkan sebagaimana musik gerejawai itu adalah respons atas karya Allah, maka dalam keseluruhan bentuk-bentuk musik dan nyanyian harus mutlak bertujuan mengungkap keagungan Allah, bukan persoalan selera atau kesukaan manusia. Setiap pengalaman rohani baik sifatnya kegembiraan maupun

${ }^{18}$ Tim Penyusun, Kidung Jemaat, Jakarta: Yamuger, 2009, no. 2 
ketenangan jiwa yang diekspresikan melalui musik dan nyanyian tunduk pada prinsip -prinsip dan otoritas kebenaran firman Allah.

\section{a. Perjanjian Lama}

Dibandingkan dengan Perjanjian Baru, kitab-kitab di dalam Perjanjian Lama jauh lebih lengkap sebagai sumber untuk menemukan berbagai bentuk nyanyian dan pujian kepada Allah. Salah satu kata yang dipakai untuk menjelasakan makna nyanyian pujian kepada Allah yang sifatnya bergembira adalah halal. Kata halal memiliki arti menjadi cemerlang, bersih dan bersinar. Kata ini biasanya dipakai untuk menyanjung, membanggakan, merayakan dengan penuh sukacita dan semangat yang menayala-nyala. Kata halal berasal dari kata yang berbentuk perintah yaitu haleluya yang memiliki arti; "Pujilah Tuhan dengan kemegahan dan penuh sukacita serta memasyurkan Dia dengan suara nyaring". Bentuk pujian halal harus dipersembahkan dalam suatu sikap yang girang dan bersukacita. Kata halal ini dapat kita lihat dalam Yeremia 31:1; Sebab beginilah firman Tuhan: Bersorak-sorailah bagi Yakub dengan sukacita, bersukacitalah tentang pemimpin bangsa- bangsa! Kabarkanlah, pujilah (halal) dan katakanlah Tuhan telah menyelamatkan umat-Nya, yakni sisa-sisa Israel."19 Beberapa contoh ayat-ayat di Perjanjian Lama yang menjelaskan tentang memuji Allah karena keperkasaan Allah seperti; Maz.69:31, Maz. 149:3, 1 Tawarik 25:1,3, 2 Tawarikh 20:21. Semangat yang menyala-nyala dalam musik dan nyanyian bukan untuk meluapkan emosi dan hasrat seni semata, melainkan mengekspresikan kebesaran Allah. Kesaksian dan pengajaran prinsipprinsip kebenaran Allah harus termuat dalam musik dan nyanyian gerejawi.

Semenatara dalam Mazmur 103:1-2 memakai kata barak; yang berarti berkat. “Dari Daud. Pujilah (barak) TUHAN, hai jiwaku! Pujilah nama-Nya yang kududs, hai segenap batinku. Pujilah TUHAN, hai jiwaku, dan janganlah lupakan segala kebaikan$N y a !^{20}$ Sebuah bentuk pujian yang dinyatakan dalam sikap tenang dan dalam keheningan sebagai tanda pengakuan dan penghormatan bahwa Allah adalah sumber berkat dan kuasa. Kata barak ini tidak menunjuk pada suatu ekspresi pujian berbentuk vokal atau ucapan, namun dalam bentuk sikap yang hening di hadapan Allah. Dari dalam jiwa menaikkan pujian kepada Allah atas keselamatan yang diberikan kepada manusia.

\section{b. Perjanjian Baru}

Ketiga corak musik seperti mazmur-mazmur, kidung puji-pujian, dan nyanyian rohani yang dimuat dalam Efesus 5:19 merupakan bentuk-bentuk pujian yang

\footnotetext{
19 Tim Penyususn, Perjanjian Lama, Ibrani - Indonesia, Jakarta: LAI, 2004, hlm. 844.

20 lbid, hlm. 1182.
} 
digunakan dalam peribadahan jemaat mula-mula. Mazmur-mazmur ialah dari Perjanjian Lama, dan kidung puji-pujian merupakan nyanyian-nyanyian yang dipakai dalam ibadah-ibadah gereja purba, serta nyanyian-nyanyian rohani merupakan nyanyian para peserta ibadah surgawi (bnd. Wahyu 5:9; 14:13; 15:3). ${ }^{21}$ Segala nyanyian pujian, mazmur serta nyanyian rohani haruslah dipersembahkan hanya kepada Allah saja (19). Musik gereja adalah bentuk pengajaran akan firman Allah (Kol. 3:16). Jemaat secara bersama-sama menaikkan mazmur, kidung pujian, nyanyian rohani kepada Tuhan, disaat yang sama sedang memperdengarkan dan mengajarkan kebenaran Firman Allah antara yang satu dengan lainnya.

Bentuk-bentuk musik dan nyanyian lainnya dalam Perjanjian Baru dijelaskan dalam kitab Wahyu. Bentuk-bentuk nyanyian dalam kitab Wahyu lebih bercorak eskatologis, yang menggambarkan kemuliaan yang Agung dari sang Raja yaitu Tuhan Yesus Kristus. Seperti dalam Wahyu 4:9-11, 5: 9-13, 7:12, 13:3, 15:3, 19:5 : menekankan musik dan nyanyian yang eskatologis. Allah Abraham, Isak dan Yakub adalah Allah yang sama yang kita sembah di dalam Yesus Kristus. Ia telah berkarya pada masa lampau, masa sekarang dan masa yang akan datang dan karya - karya-Nya merupakan dasar dan corak dari semua musik gerejawi. Bentuk nyanyian adalah merupakan ekspresi iman atas pekerjaan tangan Tuhan yang telah kita terima, namun juga merupakan bentuk pengakuan kita akan pengharapan dimasa mendatang.

\section{Siapa Dan Bagaimana Mempersembahkan Musik Gerejawi Kepada Tuhan?}

\section{a. Perjanjian Lama}

Selain para malaikat-malaikat Allah di surga juga setiap umat pilihan Allah diperintahkan untuk menyembah Dia dengan segala jenis musik dan nyanyian $(b d k$. Maz. 150). Namun demikian dalam Perjanjian Lama dijelaskan bahwa ada semacam aturan-aturan yang harus diiktui oleh bangsa Isreal untuk menaikkan penyembahan pujian mereka kepada Allah. Ada yang bertugas khusus untuk memimpin ibadah maupun memainkan musik dan nyanyian kepada Tuhan Allah. Para pelayanan musik dan nyanyian tersebut telah ditetapkan menjadi tugas pokok bagi salah satu suku Israel yaitu suku Lewi. Setiap ibadah akan dilaksanakan, maka orang-orang yang akan memainkan musik dan nyanyian pujian kepada Tuhan akan dikendalikan oleh kaum suku Lewi. Para penyanyi suku Lewi, yang diangkat oleh Daud untuk bertugas memainkan musik di Bait Suci Yerusalem telah benar-benar ditempatkan dalam "komunitas kultis" 22 (band. I Taw 6; 15; 16; 25; 29; 2 Taw 35:15). Kapanpun mereka

${ }^{21}$ Tim Penyususn, Tafsiran Masa Kini 3, hlm.602.

${ }^{22}$ Komunitas kultis maksudnya adalahkomunitas yang benar-benar taat dalam menjalakan tugas mereka sebagai pemandu musik dan nyanyian peribadahan. 
diangkat, itu akan menjadi tanggung jawab mereka untuk tetap memuji Allah dengan kecapi, gambus, dan ceracap (1 Taw 25:1). Dalam 1 Tawarik 15:27, 1 Tawarik 6: 7, 1Tawarik 15 : 21, dan 1 Tawarik 25, Raja Daud mengangkat secara teknis kelompokkelompok yang bertugas bernyanyi dan bermain musik di dalam Rumah Tuhan.

Mengenai sikap dalam memuji dan menyembah Allah, 2 Samuel 6:5, Amos 5:23-24, menjadi sebuah pentunjuk yang jelas bahwa hidup setiap orang yang menaikkan musik dan nyanyian kepada Tuhan harus berpadanan dengan kehendak Tuhan.Daud bersama dengan kaum Israel sekuat tenaga menari di hadapan Tuhan dengan diiringi musik dan nyanyian oleh karena sukacita mereka di dalam Tuhan. Sekuat tenaga menunjukkan sikap kesungguhan untuk memuji Allah, tidak bermainmain seperti Uza ketika sedang di hadapan Allah (band. 2 Samuel 6:6-7). Kesungguhan hidup benar di hadapan Allah sebagai syarat bagi setiap orang yang mau memuji dan memuliakan Allah. Hal itu juga sangat jelas dinyatakan dalam Amos 5:23-24 yang berbunyi;"Jauhkanlah daripada-Ku keramaian nyanyian - nyanyianmu, lagu gambusmu tidak mau Aku dengar. Tetapi biarlah keadilan bergulung-gulung seperti air dan kebenaran seperti sungai yang selalu mengalir."Bagaimana mungkin seseorang menyanyikan nyanyian-nyanyian rohani, namun hidupnya penuh dengan dusta dan ketidakadilan. Penyembah -penyembah yang demikian bukanlah yang dikehendaki Allah. Setiap orang yang mau menyembah dan memuji Allah harus selaras dengan perlikau hidupnya yang dituntun oleh sifat -sifat Allah dalam firmanNya.

\section{b. Perjanjian Baru}

Bagaimana seharusnya sikap seseorang ketika sedang menaikkan nyanyian pujian kepada Allah pada ayat 19 dan 21 dijelasakan, yaitu dengan segenap hati serta merendahkan diri. Kata tunduk dalam bahasa Yunani ialah hypotassomenoi yang diterjemahakan kedalam bahasa Indonesia (TB) dengan rendahkanlah merupakan pengertian yang telah diuraikan mengenai peraturan gereja ketika sedang melakukan sebuah peribadahan dan kehadiran Tuhan dirasakan. ${ }^{23}$ Sikap tunduk artinya adalah pengakuan diri terhadap kemahakuasaan Kristus dalam pujian yang sedang kita naikkan. Sementara dalam Yakobus 5:13 berkata; Kalau ada seorang di antara kamu yang menderita, baiklah ia berdoa! Kalau ada seorang yang bergembira baiklah ia menyanyi! Yakobus ingin mengingatkan bahwa peristiwa suka maupun duka dalam kehidupan kita harus selalu melekat kepada Tuhan. Keadaan suka harus mendorong untuk menyanyi memuji Tuhan, sementara keadaan duka harus mendorong kita untuk berdoa kepada Tuhan.

\footnotetext{
${ }^{23}$ Ibid.
} 
Saat menyembah Tuhan hal yang paling utama yang harus dimiliki setiap orang percaya adalah cinta. Musik dan nyanyian adalah ungkapan cinta kita kepada Allah. Banyak cara yang dapat dilakukan untuk mengekspresikan cinta kepada Tuhan. Dari masa ke masa berbagai macam cara yang berbeda-beda dari gereja-gereja Tuhan untuk mengekspresikan cintanya kepada Tuhan. Hal itu sangat dipengaruhi oleh perubahan-perubahan kebudayaan. Ekspresi cinta tidak bisa dipaksakan sebab hal itu munculnya dari hati. Tidak salah jika seorang memuji Tuhan meggunakan Kidung Jemaat, asal ia mengekspresikan cintanya kepada Tuhan melalui Kidung Jemaat tersebut. ${ }^{24}$ Demikian pula dengan seseorang yang mengekspresikan cintanya dengan mengangkat kedua tangannya sambil melompat-lompat bergembira namun bukan karena menikmati lagu-lagu kesayangan melainkan karena sedang mengekspresikan betapa besar cintanya kepada Tuhan. Oleh karena itu perlu diketahui bahwa mengeskpresikan cinta kita kepada Tuhan memang bisa berbeda - beda, tetapi ekspresi yang berbeda-beda itu harus dikontrol oleh otoritas kebenaran firman Allah. Bagaimana firman Allah mengontrol umat dalam mengekspresikan cintanya kita kepada Tuhan, yakni melalui dua hal penting; yang pertama adalah bahwa mengekspresikan cinta tidak boleh sembarangan melainkan harus berjalan dengan sopan dan teratur (band. 1 Kor. 14:40), dan yang kedua adalah semua nyanyian pujian harus mengandung pengajaran kebenaran Allah.

Dalam 1 Korintus 14:15: Paulus meminta jemaat untuk memperhatikan keseimbangan dalam hal iman mereka termasuk dalam permainan alat musik ataupun nyanyian yang harus dilakukan dengan pemahaman yang benar. Keseimbangan antara spiritualitas dan akal budi. Kebaktian yang meliputi unsur nyanyian harus didasari oleh akal budi di samping aspek semangat. ${ }^{25}$ Aspek akal budi dalam bermusik adalah dasar dari kemampuan seseorang dalam menciptakan nyanyian-nyanyain. Akal budi akan menyelaraskan sebuah nyanyian dengan kebenaran Firman Allah. Sehingga ekspresi dan semangat dalam bernyanyi untuk memuliakan Tuhan selalu didasari oleh teologi yang benar. Sebagaimana Allah itu adalah Roh, maka penyembahan-penyembahan kita juga harus di dalam roh dan kebenaran (lihat Yohanes 4:23). Penyembahan yang kita lakukan dengan menggunakan musik dan nyanyian bukan hanya dorongan dari tradisi-tradisi atau upacara-upacara lahiriah saja. Namun harus dipimpin oleh Roh Allah supaya musik dan nanyian itu bersesuaian dengan sifat-sifat Allah. ${ }^{26}$

Firman Allah adalah dasar dari setiap penyembahan gereja. Seluruh perjalanan pertumbuhan orang-orang Kristen diawali dengan doktrin dan kemudian

\footnotetext{
${ }^{24}$ Winnardo Saragih, Misi Musik, hlm. 94.

$25 \mathrm{Ibid}, \mathrm{hlm} .509$.

${ }^{26}$ Tim Penyusun, Tafsiran Masa Kini, hlm. 280.
} 
dialami, bukan diawali dengan pengalaman yang disusun menjadi sebuah doktrin dan lalu diajarkan pada orang-orang lain melalui nyanyian-nyanyian. Pengenalan akan Kasih Karunia Allah dalam hidup kita mendahului semua pengalaman iman kita. Sehingga kita tidak menyembah Allah yang tidak kenal. ${ }^{27}$ Dengan demikian musik dan nyanyian gerejawi itu sungguh-sungguh merupakan sebuah pergumulan yang dipimpin oleh Roh untuk menceritakan keagungan sifat-sifat Allah. Allah menghendaki penyembah - penyembah yang demikian.

\section{Kapan Dan Di mana Musik Gerejawi Dipersembahakan Kepada Tuhan?}

\section{a. Perjanjian Lama}

Ada kalanya ketika seseorang menjadi peserta diskusi-diskusi yang berkenaan dengan topik penyembahan nyanyian pujian kepada Allah dan ketika ia mendapat sebuah pertanyaan; kapan dan di mana seharunya kita harus bernyanyi untuk Tuhan? Maka dengan mudah dia dapat menjawab pertanyaan tersebut, yaitu kapan saja dan dimana saja! Namun pada realitanya mengapa sering kali ada orang yang dengan mudah menjawab pertanyaan demikian namunmasih memiliki kekwatiran untuk memuji Allah dalam kesehariannya? Jawabanya ialah karena sumber jawaban yang diberikan itu tidak memiliki landasan yang kokoh. Dia hanya mendengar dari orang lain tanpa menyelidiki lebih lanjut apa kata firman Allah mengenai kapan dan di mana seharusnya kita memuji dan menyembah-Nya. Kebenaran firman Allah adalah ibarat bahan bakar yang memiliki oktan yang sempurna sehingga mampu mendorong setiap orang percaya yakin dan berani untuk menyembah Allah dalam kehidupannya.

Dalam kitab-kitab Perjanjian Lama menjelaskan bahwa penyembahan kepada Allah melalui musik dan nyanyian tidak terbatas pada tempat-tempat dan waktu waktu tertentu. Sebab kenyataannya bahwa Allah bekerja bagi umat-Nya tidak dibatasi oleh ruang dan waktu. Ketika Musa dan bangsa Israel tiba di seberang Laut Teberau oleh karena pertolognan Allah maka; Pada waktu itu Musa bersama-sama dengan orang Israel menyanyikan nyanyian ini bagi Tuhan yang berbunyi: "Baiklah aku menyanyi bagi Tuhan, sebab ia tinggi luhur, kuda dan penunggangnya dilemparkanNya ke dalam laut....." (Kel. 15:1).

Dalam keseharian dan di mana saja ketika mengalami perjumpaan dengan Allah melalui mujizat-mujizat-Nya, maka untuk merespons akan hal itu musik dan nyanyian pujian kepada Allah adalah yang terbaik. Dalam peperangan merebut Yerikho, Yosua bersama dengan imam-imam dan bala tentaranya menggunakan musik dan nyanyian kepada Allah. Dengan tiupan sangkakala dari para imam sebagai

\footnotetext{
${ }^{27}$ Will Metzger, Tell The Truth, hlm. 180.
} 
pertanda bahwa Allah akan merobohkan Tembok Yerikho dan memberikan kota itu kepada mereka, maka mereka bersorak bagi Tuhan (Yosua 6).

Baru dalam 2 Samuel 6:5, Amos 5:23: menjadi sutau pentunjuk yang jelas sekali bahwa musik dan nyanyian adalah biasa dimainkan dalam pelaksanaanpelaksanaan peribadahan bangsa Israel. Bukan saja soal nyanyian yang dikumandakan dalam peribadahan bangsa Israel, namun juga ayat ini, menegaskan bagaimana seharusnya hidup setiap orang yang menaikkan musik dan nyanyian itu bagi Tuhan harus berpadanan dengan kehendak Tuhan.

\section{b. Perjanjian Baru}

Sama halnya dengan Perjanjian Lama setiap musik dan nyanyian dikumandangkan bagi Allah yang telah menebus umat-Nya. Pujian dan penyembahan kepada Allah tidak dibatasi ruang dan waktu. "Dengan bertekun dan dengan sehati mereka berkumpul tiap-tiap hari dalam Bait Allah. Mereka memcahkan roti di rumah masing-masing secara bergilir dan makan bersama-sama dengan gembira dan dengan tulus hati sambil memuji Allah...." (Kisah Para Rasul 2:46,47a). Baik di Sinagoge maupun di rumah-rumah jemaat secara bergilir setiap hari jemaat mula-mula selalu memuji Allah. Musik gereja tidak bergantung pada keadaan manusia. Baik atau buruk waktunya musik gereja harus selalu dikumandangkan untuk menyatakan kemuliaan Allah. Dipenjara Paulus dan Silas memuji Allah. (Kis. 16:25, band. Yakobus 5:13).

Yesus berkata kepada perempuan Samaria dalam Yohanes 4:21; Kata Yesus kepadanya:" Percayalah kepada-Ku, hai perempuan, saatnya akan tiba, bahwa kamu akan menyembah Bapa bukan di gunung ini dan bukan juga di Yerusalem." Latar belakang percakapan Yesus dengan perempuan Samaria ini sesungguhnya adalah pertentangan tradisi keagamaan yang melekat pada orang-orang Yahudi dan orangorang Samaria mengenai di mana mereka harus menyembah Allah. Hal-hal yang dipersoalkan adalah menyangkut masalah-masalah lahiriah dalam penyembahan seperti lokasi, tata cara, tradisi dan keyakinan agama mereka. Apakah mereka harus menyembah Allah di Yerusalem, sebagaimana yang dipertahankan oleh bangsa Yahudi atau di Gunung Gerizim, sebagaimana yang dilakukan oleh orang-orang Samaria. ${ }^{28}$ Namun Yesus telah menghapuskan semua pertimbangan-pertimbangan itu, dan memusatkan penyembahan kepada Allah tersebut pada inti yang sesungguhnya yaitu penyembahan yang bersifat pribadi kepada-Nya. Penyembahan yang sifatanya sangat personal tersebut harus dilakukan di dalam roh dan kebenaran. Roh Kudus yang menggerakan setiap roh yang ada dalam diri setiap orang percaya menyembah Allah sesuai dengan kebenaran-Nya.

\footnotetext{
${ }^{28}$ Graham Kendrick, Pujian Dan Penyembahan, hlm. 71
} 
Peristiwa perjumpaan Yesus dengan perempuan Samaria menjadi semacam pengumuman tempat Ibadah yang baru dalam memuji dan menyembah Allah. Sebagaimana yang dinyatakan oleh rasul Paulus dalam Roma 12:1; Karena itu saudara-saudara, dengan kemurahan Allah aku menasihatkan kamu, supaya kamu mempersembahkan tubuhmu sebagai persembahan yang hidup, yang kudus dan yang berkenan kepada Allah, itulah ibadahmu yang sejati. Karena kita ini buatan Allah yang telah ditebus oleh Yesus Kristus maka penyembahan kita melalui musik dan nyanyian kepada Allah tidak lagi terbatas pada tempat upacara-upacara perayaan pada kebaktian di dalam gedung-gedung tertentu, melainkan melalui seluruh eksistensi kehidupan kita, harus menjadi pujian yang memuliakan Tuhan (band. 1 Kor. 6:19). Musik dan nyanyian bagi Tuhan akan menjadi nyata dalam hidup keseharian kita karena terus mengalami perjumpaan dengan Allah. Roh-Nya akan menggerakkan roh kita untuk memuji Allah dalam kebenaran-Nya.

\section{Kesimpulan}

Musik dan nyanyian pada masa sekarang mengalami banyak perkembangan, banyak ragam ekspresi dari umat dalam bermain musik dan bernyanyi dalam sebuah kebaktian gereja. Alat-alat instrumen yang serba elektrik juga telah ikut mempengaruhi suasana kebaktian. Efek suara dari musik yang berdaya listrik ribuan watt telah menciptakan suasana hingar-bingar dalam ibadah. Namun dari semua itu yang paling penting adalah bahwa dalam setiap musik dan nyanyian penyembahan tersebut harus ada persekutuan dengan Roh Kudus. Roh Kudus akan memimpin penyembahan kepada Allah yang selaras dengan kebenaran-Nya. Tanpa itu maka musik dan nyanyian gerejawi tidak lebih dari sekedar entertainment (hiburan) bagi seluruh jemaat. Mereka hanya menunggu kapan mulai dimainkan musik dan bernyanyi untuk bersama-sama terhibur dan menghibur satu dengan yang lainnya, namun dari segi kualitas rohani mereka tidak bertumbuh.

Sebagaimana ketika seseorang ingin membuat hati orang yang dicintainya berbunga-bunga dan tersanjung maka dia akan memebrikan sesuatu barang yang sangat disuakai oleh orang yang dicintainya tersebut. Demikianlah sebaiknya sikap setiap orang percaya kepada Allah yang telah menebusnya. Allah berkehendak segala musik yang terbaik dan nyanyian dipersembahkan kepada-Nya sebagai respon atas kebesaran pekerjaan Tangan-Nya dalam hidup umat pilihan-Nya. Demikianlah Musa dan bangsa Israel telah bernyanyi untuk memuliakan Allah karena pertolongan-Nya. Daud telah memuji-muji Allah oleh karena Keagungan-Nya, demikian pula perempuan Samaria itu telah berubah menjadi berani dan yakin untuk menjadi saksiNya kerena telah berjumpa dengan Air Hidup yang kekal itu, serta Paulus dan Silas telah sanggub bernyanyi memuji Tuhan di tengah-tengah penderitaan yang mereka 
alami. Demikianlah kiranya setiap gereja Tuhan mempersembahan musik dan nyanyiannya sebagai penyembahan kepada Allah didalam roh dan kebenaran-Nya. Dari dulu hingga sekarang Allah terus mencari penyembah-penyembah yang benar, yang menyembah Bapa di dalam roh dan kebenaran-Nya. Biarlah segala yang bernafas memuji Tuhan! Haleluya! (Mazmur 150:6).

\section{Referensi}

Tim Penyususn, Alkitab, Jakarta: LAI, 2008

Tim Penyusun, Perjanjian Lama, Ibrani - Indonesia,Jakarta: LAI, 2004

Tim Penyusun, Tafsiran Masa Kini 1, Jakarta: Yayasan Komunikasi Bina Kasih, 2008

Tim Penyusun, Tafsiran Masa Kini 2, Jakarta: Yayasan Komunikasi Bina Kasih, 2009

Tim Penyusun, Tafsiran Masa Kini 3, Jakarta: Yayasan Komunikasi Bina Kasih, 2010

Tim Penyusun, Kidung Jemaat, Jakarta: Yamuger, 2009

Kendrick, Graham, Pujian Dan Penyembahan,Jakarta: Mimery Press,1984

Metzger, Will, Tell The Truth,Surabaya: Momentum, 2005

Saragih, Winnardo, Misi Musik, Yogyakarta: Andi, 2008

Djohan, Psikologi Musik, Yogyakarta: Kanisius, 2020-05-24

McNeill, Roderick J. Sejarah Musik 1, Jakarta: BPK Gunung Mulia, 2016

Boschman, Lamar, Musik Bangkit Kembali, Jakarta: Yayasan Pekabaran Injil Imanuel, 2001

Dyrness, William A, Agar Bumi Bersukaita, Jakarta: BPK Gunugn Mulia, 2004

Smith, Jane Stuart dan Betty Carlson, Karunia Musik, Surabaya: Momentum, 2003

Selvaraj, Sadhu Sundar, Seni Menyembah, Jakarta: Nafiri Gabriel, 1996

Osbeck, Kenneth W. Amazing Grace, United States: Kregel Publications, 1990 